ISSN (print): 1698-6180. ISSN (online): 1886-7995

www.ucm.es/info/estratig/journal.htm

Journal of Iberian Geology 36 (2) 2010: 243-252

doi:10.5209/rev_JIGE.2010.v36.n2.10

\title{
New stegosaurian (Ornithischia, Thyreophora) remains from Jurassic-Cretaceous transition beds of Valencia province (Southwestern Iberian Range, Spain).
}

\author{
Nuevos restos de estegosaurios (Ornithischia, Thyreophora) del \\ tránsito Jurásico-Cretácico de la provincia de Valencia (Cordillera \\ Ibérica Suroccidental, España)
}

\author{
J. Company ${ }^{1}$, X. Pereda Suberbiola ${ }^{2}$, J.I. Ruiz-Omeñaca ${ }^{3,4}$ \\ ${ }^{1}$ Departamento de Ingeniería del Terreno, Universidad Politécnica de Valencia, 46022 Valencia, Spain. company@uv.es \\ ${ }^{2}$ Universidad del País Vasco/Euskal Herriko Unibertsitatea, Facultad de Ciencia y Tecnología, Departamento de \\ Estratigrafia y Paleontología, Apartado 644,48080 Bilbao,Spain.xabier.pereda@ehu.es \\ ${ }^{3}$ Museo del Jurásico de Asturias (MUJA), 33328 Colunga, Spain \\ ${ }^{4}$ Grupo Aragosaurus-IUCA (www.aragosaurus.com), Area de Paleontología, Facultad de Ciencias, \\ Universidad de Zaragoza, 50009 Zaragoza,Spain.jigruiz@unizar.es
}

Received: 20/11/09 / Accepted: 30/06/10

\begin{abstract}
New stegosaurian remains have been recently recovered from the Jurassic-Cretaceous transition sandstones of the Villar del Arzobispo Formation (Tithonian-Berriasian) in the Valencia province, eastern Spain. Specimens consist of two partially articulated (or closely associated) postcranial skeletons. The Baldovar specimen is composed of appendicular bones (scapula, femur) and two pairs of dermal tail spines, two of them articulated with two distal caudal vertebrae. The second specimen, unearthed in the vicinity of La Yesa village, consists of dorsal vertebrae and ribs, fragments of caudal centra and an incomplete femur. The new specimens are tentatively referred to the clade Dacentrurinae and may belong to Dacentrurus on the basis of features observed on the dorsal vertebrae and caudal dermal spines. Stegosaurs are represented so far in the Jurassic-Cretaceous transition of Spain by Dacentrurus. The presence of other taxa (Stegosaurus, Miragaia) in Spain, recently documented in the Late Jurassic of Portugal, cannot be attested on the basis of the currently recorded material.
\end{abstract}

Keywords: Dinosauria, Stegosauria, Dacentrurus, Iberian Range, Tithonian-Berriasian, Iberian Peninsula 


\section{Resumen}

Nuevos restos fósiles de estegosaurios han sido recientemente hallados en niveles de areniscas del tránsito Jurásico-Cretácico de la formación Villar del Arzobispo (Titónico-Berriasiense) en la provincia de Valencia. Los especímenes consisten en dos esqueletos postcraneales parcialmente articulados (o en relación anatómica). El ejemplar de Baldovar consta de huesos apendiculares (escápula, fémur) y dos pares de espinas dérmicas de la cola, dos de ellas articuladas con dos vértebras caudales distales. Por su parte, el ejemplar de La Yesa se compone de vértebras dorsales y costillas, fragmentos de centros caudales y un fémur incompleto. Los fósiles se atribuyen al clado Dacentrurinae y podrían pertenecer a Dacentrurus en función de caracteres observados en las vértebras dorsales y las espinas dérmicas caudales. Los estegosaurios están representados hasta la fecha en el tránsito Jurásico-Cretácico de España por Dacentrurus. No puede confirmarse por el momento la presencia de otros taxones que están documentados en los yacimientos del Jurásico superior de Portugal (Miragaia, Stegosaurus).

Palabras clave: Dinosauria, Stegosauria, Dacentrurus, Cordillera Ibérica, Titónico-Berriasiense, Península Ibérica

\section{Introduction}

Omosaurus armatus, from the Early Kimmeridgian of Wiltshire (England), was the first articulated stegosaur described in the world and is the type species of Dacentrurus. Dacentrurus has been subsequently cited in other Late Jurassic localities of England, France and Portugal (see references in Galton and Upchurch, 2004; Weishampel et al., 2004; Maidment et al., 2008), and in several Late Jurassic-Early Cretaceous localities of Spain (see below).

Until recently, Dacentrurus was the only stegosaur documented in the Late Jurassic of Europe. However, remains of Stegosaurus and Miragaia have been described in the Late Kimmeridgian-Early Tithonian of Portugal (Escaso et al., 2007, 2008; Mateus, et al., 2009).

In Spain, remains of Dacentrurus have been recovered from several localities of the Jurassic-Cretaceous transition at the Iberian Range (Teruel and Valencia provinces, see Table 1). In addition, a dorsal vertebra and a dermal plate from the Early Cretaceous of Burgos, originally referred to an indeterminate stegosaur (Pereda-Suberbiola et al., 2003), were recently assigned to this genus (Maidment et al., 2008). The Spanish fossils have been referred to Dacentrurus based mainly on the presence of cervical ribs fused to respective vertebrae and/or dorsal vertebrae provided with wider than longer centra, features considered at present as synapomorphies of the clade Dacentrurinae (Mateus et al., 2009). These materials should be restudied in order to clarify its referral to Dacentrurus, Miragaia or to another undefined dacentrurine (RuizOmeñaca et al., 2009).

In this paper we describe preliminarily new stegosaurian material from the Tithonian-Berriasian Villar del Arzobispo Formation cropping out near the villages of $\mathrm{La}$ Yesa and Baldovar (Valencia province, eastern Spain). The affinities of this material are discussed. Comparisons are made with the clade Dacentrurinae, and more specifically with Dacentrurus, the only stegosaur genus docu- mented so far in the Spanish record.

Institutional abbreviations.- NHMUK, The Natural History Museum, London, UK; MCNV, Museo de Ciencias Naturales de Valencia, Spain; MPA, Museo Paleontológico de Alpuente, Valencia province, Spain; YPM: Yale Peabody Museum, New Haven, USA.

\section{Location and Geological setting}

The fossils consist of two partly articulated skeletons of stegosaurian dinosaurs unearthed from exposures of the lower part of the Villar del Arzobispo Formation in the South Iberian sub-basin of the Iberian basin (Southwestern Iberian Range). The new localities are placed near the villages of Baldovar (Barranco del Curro site) and La Yesa (El Balsón site), Valencia province, eastern Spain (Fig. 1).

The area exhibits extensive exposures of Upper Jurassic-Lower Cretaceous sediments represented by the transitional Villar del Arzobispo Formation (TithonianBerriasian), unconformably overlain by the more regressive El Collado Formation (Barremian). These units constitute an approximately 500-m-thick succession of interbedded bioclastic limestones, calcarenites and marly claystones, changing with the beginning of the second formation to a more siliciclastic sequence composed of sandstones, red and grey mudstones and locally conglomerates, in which subtidal to intertidal and supratidal facies have been recognized (Mas et al., 1984; Luque et al., 2005). The succession represents the installation of a regressive episode that took place during the JurassicCretaceous transition. Both coastal non-marine units, known informally as "Purbeckian" and "Wealden" facies, have produced abundant remains of dinosaurs, including large sauropods, indeterminate theropods and stegosaurs. In this regard, the Villar del Arzobispo Formation is by far the most productive unit of the Iberian Range, and has yielded a number of fossiliferous localities, mainly concentrated in the South Iberian sub-basin (Ruiz-Omeñaca 


\begin{tabular}{|c|c|c|c|c|}
\hline Taxon & Localities (province) & Age (Formation) & Material & References \\
\hline ?Stegosauria indet. & $\begin{array}{l}\text { "Castellote NE", in } \\
\text { Castellote (Teruel) }\end{array}$ & $\begin{array}{l}\text { Lower Barremian-basal } \\
\text { Aptian (Artoles Fm.) }\end{array}$ & Dorsal vertebrae & $\begin{array}{l}\text { Ruiz-Omeñaca (2000); } \\
\text { Maidment et al. }(2008)^{*} \\
\text { *:as Dinosauria indet. }\end{array}$ \\
\hline Stegosauria indet. & $\begin{array}{l}\text { "Barranco Espina", in } \\
\text { Galve (Teruel) }\end{array}$ & $\begin{array}{l}\text { Lower Barremian } \\
\text { (Camarillas Fm.) }\end{array}$ & Dermal spine & $\begin{array}{l}\text { Pereda-Suberbiola et al. } \\
(2005) \text {; Maidment et al. } \\
(2008)^{*} \\
{ }^{*} \text { : as Thyreophora indet. }\end{array}$ \\
\hline Stegosauria indet. & $\begin{array}{l}\text { "Aldea del Pinar", in } \\
\text { Hontoria del Pinar } \\
\text { (Burgos) }\end{array}$ & $\begin{array}{l}\text { Hauterivian-Barremian } \\
\text { (Piedrahita de Muñó Fm.) - } \\
\text { provisional age }\end{array}$ & $\begin{array}{l}\text { Dorsal vertebra and dermal } \\
\text { plate }\end{array}$ & $\begin{array}{l}\text { Pereda Suberbiola et al. } \\
(2003) \text {; Maidment et al. } \\
\begin{array}{l}(2008)^{*} \\
\text { *: as Dacentrurus sp. }\end{array}\end{array}$ \\
\hline Stegosauria indet. & $\begin{array}{l}\text { "La Canaleta", in Galve } \\
\text { (Teruel) }\end{array}$ & $\begin{array}{l}\text { Uppermost Hauterivian } \\
\text { (El Castellar Fm.) }\end{array}$ & Dermal spine & $\begin{array}{l}\text { Pereda-Suberbiola et al. } \\
(2005) \text {; Maidment et al. } \\
(2008)^{*} \\
\text { *: as Thyreophora indet. }\end{array}$ \\
\hline Dacentrurus & $\begin{array}{l}\text { "San Cristóbal", in El } \\
\text { Castellar (Teruel) }\end{array}$ & \multirow{9}{*}{$\begin{array}{l}\text { Tithonian-Berriasian } \\
\text { (Villar del Arzobispo Fm.) }\end{array}$} & $\begin{array}{l}\text { Dorsal and caudal vertebrae, } \\
\text { synsacrum, ischium, pubis } \\
\text { (mainly undescribed) }\end{array}$ & Cobos et al. (2009) \\
\hline Aff. Dacentrurus sp. & $\begin{array}{l}\text { "Están de Colón", "La } \\
\text { Quineta 2" and "Prado de } \\
\text { las Arenas", in Riodeva } \\
\text { (Teruel) }\end{array}$ & & Not cited (undescribed) & Cobos et al. (2008) \\
\hline Aff. Dacentrurus sp. & $\begin{array}{l}\text { "El Romeral", in Riodeva } \\
\text { (Teruel) }\end{array}$ & & Cervical and dorsal vertebrae & $\begin{array}{l}\text { Cobos et al. }(2008,2009) ; \\
\text { Cobos (2009) }\end{array}$ \\
\hline Aff. Dacentrurus sp. & $\begin{array}{l}\text { "Barrihonda-El Humero", } \\
\text { in Riodeva (Teruel) }\end{array}$ & & $\begin{array}{l}\text { Cervical and caudal vertebrae, } \\
\text { iliosacral block, ischia, pubes, } \\
\text { femur, tibia, fibula, calcaneum, } \\
\text { astragalus, dermal plate (mainly } \\
\text { undescribed) }\end{array}$ & $\begin{array}{l}\text { Cobos et al. }(2008,2009) ; \\
\text { Cobos (2009) }\end{array}$ \\
\hline Dacentrurus armatus & $\begin{array}{l}\text { "Losilla", in Aras de los } \\
\text { Olmos (Valencia) }\end{array}$ & & Dermal tail spine & $\begin{array}{l}\text { Casanovas-Cladellas et al. } \\
(1995 a, 1999)^{*} \text {; Santafé- } \\
\text { Llopis (1996); Maidment et } \\
\text { al. (2008)** } \\
\quad \text { *: as Stegosauridae indet. } \\
\quad * * .: \text { as Thyreophora indet. }\end{array}$ \\
\hline Dacentrurus armatus & $\begin{array}{l}\text { "Losilla I", in Aras de los } \\
\text { Olmos (Valencia) }\end{array}$ & & $\begin{array}{l}\text { Cervical, dorsal and caudal } \\
\text { vertebrae }\end{array}$ & $\begin{array}{l}\text { Casanovas-Cladellas et al. } \\
(1997) ; \text { Maidment et al. } \\
(2008)^{*} \\
\quad \text { *: as Dinosauria indet. }\end{array}$ \\
\hline Dacentrurus armatus & $\begin{array}{l}\text { "Cerrito del Olmo l", in } \\
\text { Alpuente (Valencia) }\end{array}$ & & $\begin{array}{l}\text { Cervical, dorsal and caudal } \\
\text { vertebrae, ribs and ischium }\end{array}$ & $\begin{array}{l}\text { Casanovas-Cladellas et al. } \\
\begin{array}{l}(1995 b) ; \text { Maidment et al. } \\
\begin{aligned}(2008)^{*} & \text { *: as Dacentrurus sp. }\end{aligned}\end{array}\end{array}$ \\
\hline Dacentrurus armatus & $\begin{array}{l}\text { "Cerrito del Olmo II", in } \\
\text { Alpuente (Valencia) }\end{array}$ & & Femur & $\begin{array}{l}\text { Casanovas-Cladellas et al. } \\
\text { (1999) }\end{array}$ \\
\hline Stegosauridae indet. & $\begin{array}{l}\text { "By Pass" and "Cañada } \\
\text { París", in Alpuente } \\
\text { (Valencia) }\end{array}$ & & $\begin{array}{l}\text { Dorsal, sacral and caudal } \\
\text { vertebrae, cervical and dorsal } \\
\text { ribs, chevron, pelvid girdle, tibia, } \\
\text { fibula and osteoderms } \\
\text { (undescribed) }\end{array}$ & Suñer \& Martín (2009) \\
\hline Dacentrurinae indet. & $\begin{array}{l}\text { "La Escalera", in } \\
\text { Villaviciosa (Asturias) }\end{array}$ & Kimmeridgian (Lastres Fm.) & $\begin{array}{l}\text { Cervical and dorsal vertebrae, } \\
\text { ribs }\end{array}$ & Ruiz-Omeñaca et al. (2009) \\
\hline
\end{tabular}

Table 1. Previous record of stegosaurian dinosaurs in the Late Jurassic and Early Cretaceous of Spain. References of Dacentrurus in Valencia Teruel and Burgos provinces are emphasized in bold. New assignments of revised material are indicated.

Tabla 1. Registro previo de dinosaurios estegosaurios en el Jurásico Superior y Cretácico Inferior de España. En negrita se destaca la presencia de Dacentrurus en las provincias de Valencia, Teruel y Burgos. Se indican las nuevas asignaciones de los materiales revisados. 


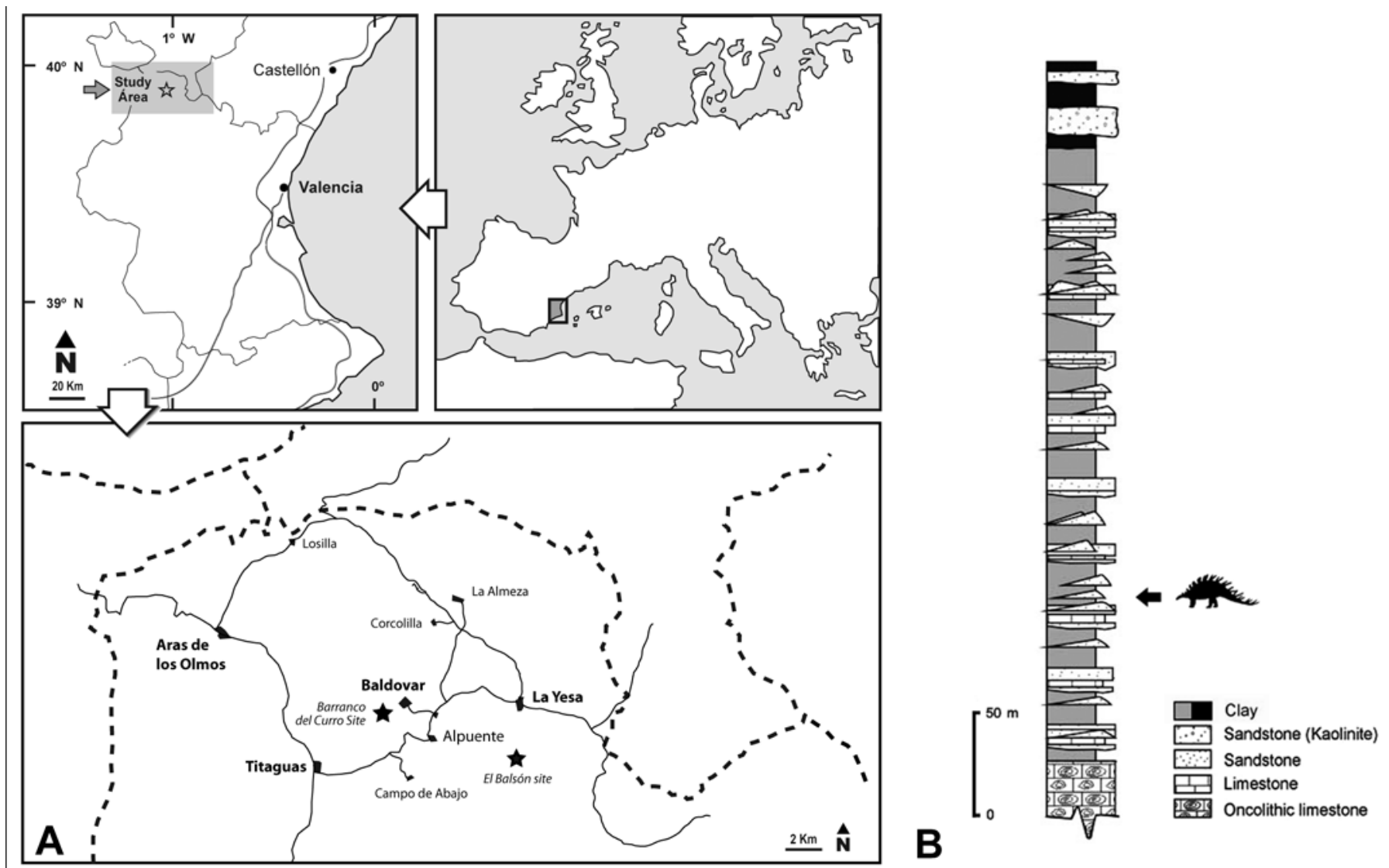

Fig. 1. A, Location maps of the fossil localities (stars) where stegosaurian specimens were collected. Insets show location of detailed maps. B, Generalized stratigraphic section of the Villar del Arzobispo Formation in the study area, showing the relative stratigraphic position of the sites (modified from Royo et al., 2006).

Fig. 1. A, Mapas de situación de los yacimientos paleontológicos (estrellas) donde han sido hallados restos de dinosaurios estegosaurios. Las selecciones indican la posición de los mapas de detalle. B, Columna estratigráfica esquemática de la Formación Villar del Arzobispo en el área de estudio, indicando la posición estratigráfica de los yacimientos (modificada de Royo et al., 2006).

and Canudo, 2003 and references therein; Royo et al., 2006, 2009) which documents a rich and diverse Tithonian-Berriasian continental vertebrate fauna.

\subsection{El Balsón site, La Yesa.}

El Balsón site occurs in the lower part of the Villar del Arzobispo Formation, which consists of greenish-gray, massive mudstones and siltstones alternating with sandstone beds. The sequence overlies coarse calcarenite deposits with abundant bivalve moulds and oysters, indicating alternation of continental and marine conditions that point out to a siliclastic tidal flat origin of the terrigenous sediments.

Fossils are concentrated in the upper part of a finegrained sand body. The stegosaurian remains consist of dorsal vertebrae and ribs, sparse fragments of caudal vertebrae, and a partial femur of a small-sized individual. These bones were found closely associated and at least some of them were preserved in close anatomical rela- tion; thus they probably belong to the same individual (Fig. 2A). Bones surface are pristine, suggesting limited transport, and absence of reworking or prolonged subaerial exposure of the carcass before burial. The material is somewhat crushed and distorted by diagenetic compactation. The sandstone deposit has also produced actinopterygian teeth and abundant carbonized plant remains.

\subsection{Barranco del Curro site, Baldovar.}

Several postcranial elements of a second stegosaur specimen were found encrusted in a sandstone slab fallen down from a lateral bank of the Barranco del Curro creek. The fossil site is located about $6.5 \mathrm{~km}$ northwest to $\mathrm{El}$ Balsón (Fig.1) site and placed at the same stratigraphic interval. The specimen has been only partially excavated, and a partial scapula, a complete femur and four dermal tail spines, two of them articulated with distal caudal centra, have been recovered to date. These remains are articulated or in close anatomical relation (Fig. 2B). Thus, 
they may belong to a single individual. Again, the presence of relatively unweathered bones with little abrasion suggests rapid burial. Coal lenses and ferruginized vegetable remains are frequent in the sandstone bed.

\section{Systematic Paleontology}

\subsection{El Balsón specimen}

Dinosauria Owen, 1842

Ornithischia Seeley, 1888

Stegosauria Marsh, 1887

Dacentrurinae Mateus, Maidment and Christiansen, 2009 Dacentrurinae indet.

(Figs. 2A, 3A-G)

Material: A partial skeleton composed at least by four dorsal vertebrae (MPA D-318/319/324/332), ten dorsal ribs (MPA D-320/322/323/330/333/335/337/338/344/34 8 ), fragments of caudal centra (uncatalogued), and a fragmentary femur (MPA D-317).

Locality and horizon: El Balsón site, near La Yesa village, Valencia province, Spain. Lower part of the Villar del Arzobispo Formation.

Age: Late Jurassic-Early Cretaceous (Tithonian-Berriasian).

\section{Description}

Dorsal vertebrae.- Four fairly complete posterior dorsal vertebrae have been recovered (Figs. 3A-C). The amphicoelous, massive centra of the dorsal vertebrae are wider transversely than long anteroposteriorly. The anterior and posterior articular faces are gently concave, with the anterior articular surface considerably expanded, especially ventrally. The lateral sides of the centra are depressed beneath the neural arch and end in a faint ventral keel, joining the anterior and posterior articular faces. The neural arch, which encloses a circular neural canal, is moderately high (the height of pedicels is more than 1.5 times the height of the centra), but not as tall as in other stegosaurs (Galton and Upchurch, 2004), acquiring a columnar aspect. The neural arch exhibits a sagittal, well marked ridge extending from the base of the postzygapophyses to the neural canal. A similar, but faint ridge runs the midline of the front of the neural arch.

The parapophyses, oval-shaped in outline, are placed lateral to the prezygapophyses in the recovered specimens, beneath the transverse processes, indicating a posterior position of the dorsals in the vertebral column. The transverse processes are long, stout, and exhibit a triangular cross section. They are upwardly directed and oriented approximately $25-30^{\circ}$ above the horizontal. The
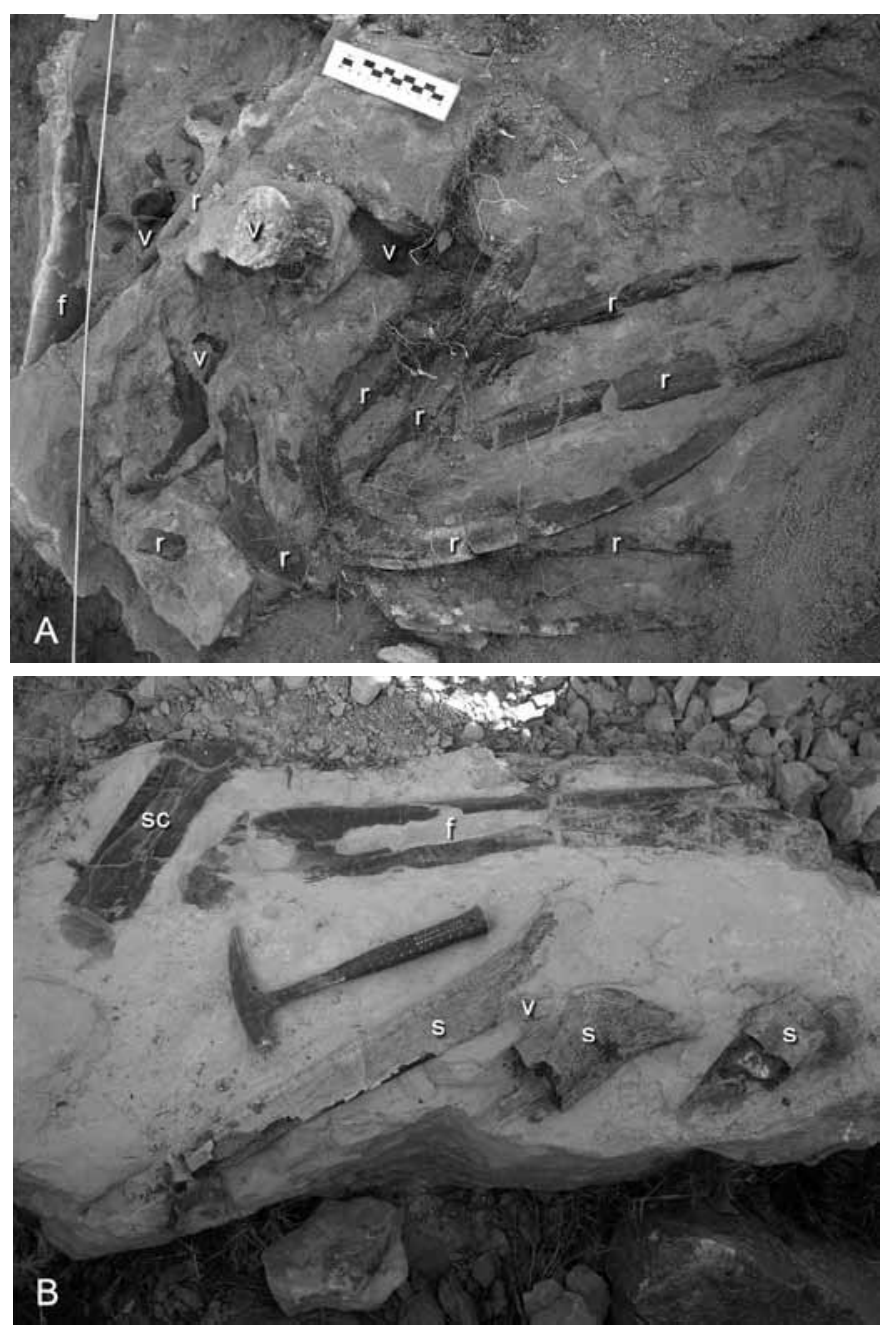

Fig. 2. Field photographs from El Balsón (A) and Barranco del Curro (B) sites (Valencia province, Spain). Abbreviations: f, femur; r, rib; s, dermal spine; sc, scapula; v, vertebra. Scale $=20 \mathrm{~cm}$.

Fig. 2. Fotografías de los yacimientos de El Balsón (A) y Barranco del Curro (B) (provincia de Valencia, España). Abreviaturas: f, fémur; r, costilla; s, espina dérmica; sc, escápula; v, vértebra. Escala $=20 \mathrm{~cm}$

prezygapophyses, whose articular surfaces are oriented upwards, inwards and slightly forwards, are ventromedially fused, but not the postzygapophyses, which are ventrally separated at the base of the neural spine by a rounded notch. The neural spine is short, moderately thickened distally and slightly directed backwards.

Dorsal ribs.- The ribs are slender elements provided of a long shaft, a reduced tuberculum and a well developed neck ending in a long capitulum (Figs. 3D-E). The cross section of the proximal half of the shaft is T-shaped, with the flat surface at its outside.

Femur.- Only a fragmentary femur $700 \mathrm{~mm}$ long has been preserved (Figs. 3F-G). It lacks the proximal third region and most of the distal end. The shaft is straight, elliptical in cross section, and the fourth trochanter is scarcely perceptible. 


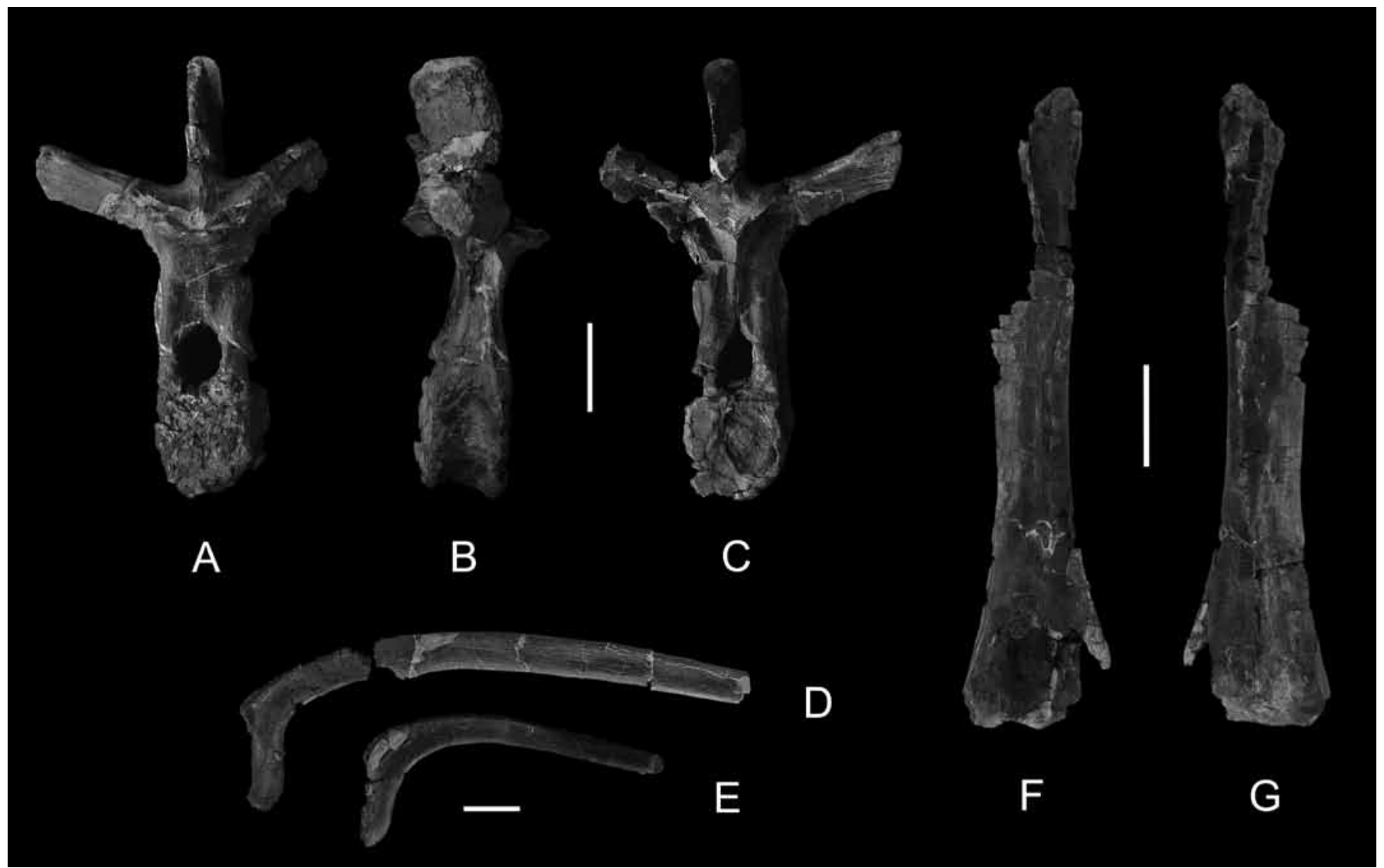

Fig. 3. Stegosaurian remains (Dacentrurinae indet.) from the Villar del Arzobispo Formation at Valencia province, Spain (El Balsón site). A-C, dorsal vertebra (MPA D-332) in anterior (A), right lateral (B) and posterior (C) views. D-E, ribs (MPA D-333, MPA D-348) in lateral view. F-G, femur (MPA D-317) in anterior $(\mathbf{F})$ and posterior $(\mathbf{G})$ views. Scale bar from A-E = $5 \mathrm{~cm}$; scale bar from F-G $=10 \mathrm{~cm}$.

Fig. 3. Restos de dinosaurios estegosaurios (Dacentrurinae indet.) de la Formación Villar del Arzobispo (El Balsón, provincia de Valencia, España). A-C, vértebra dorsal (MPA D-332) en vistas anterior (A), lateral derecha (B) y posterior (C). D-E, costillas (MPA D-333, MPA D-348) en vista lateral. F-G, fémur (MPA D-317) en vistas anterior $(\mathbf{F})$ y posterior $(\mathbf{G})$. Escala en A-E $=5 \mathrm{~cm}$; escala en F-G $=10 \mathrm{~cm}$.

\section{Discussion}

The dorsal vertebrae from El Balsón site have massive centra that are wider than long. This character is regarded as a synapomorphy of the dacentrurines Dacentrurus (Galton and Upchurch, 2004; Maidment et al., 2008) and Miragaia (Mateus et al., 2009). Moreover, the vertebrae share two characters with those of Dacentrurus armatus (holotype, BMNH 46013). First, the ratio of the neural arch height (measured from the top of the centrum to the base of the prezygapophyses) to the neural canal height is approximately 2.63 ; this value is similar to that of $D$. armatus (2.60 in Maidment et al., 2008). Second, the ratio of the centrum height to the neural arch height is about 0.74 (this value is comparable to that $(0.8)$ observed in $D$. armatus and Stegosaurus armatus (YPM 1850 and other specimens listed by Maidment et al., 2008).

These vertebral characters cannot be tested in Miragaia longicollum because only two anterior dorsal vertebrae are known in this taxon (Mateus et al., 2009). The dor- sal vertebrae of La Yesa specimen have the ventral surfaces of the prezygapophyses fused where they meet on the midline, forming a concave, continuous U-shaped surface, as occurs commonly in stegosaurs and, convergently, in ankylosaurs (Maidment et al., 2008). In the clade Lexovisaurus (Loricatosaurus according to Maidment et al., 2009; see also Buffetaut and Morel, 2009) + Stegosaurus + Dacentrurinae, the prezygapophyses are fused in all dorsal vertebrae, but in other stegosaurs the fusion only occurs on the middle and posterior dorsals (Mateus et al., 2009). The dacentrurines Dacentrurus and Miragaia are coded as "?" for inapplicable by Mateus et al. (2009). Finally, the transverse processes of $\mathrm{La}$ Yesa stegosaur project about $25^{\circ}-30^{\circ}$ to the horizontal, as is in the dorsal vertebrae of Dacentrurus armatus $\left(35^{\circ}\right.$ in the holotype BMNH 46013; Galton, 1985: Fig. 6B; see also Galton, 1991 for referred material at the Musée d'Histoire Naturelle du Havre destroyed in 1944). This angle is higher in other stegosaurs, such as Huayangosaurus, Kentrosaurus, Lexovisaurus and Stegosaurus 


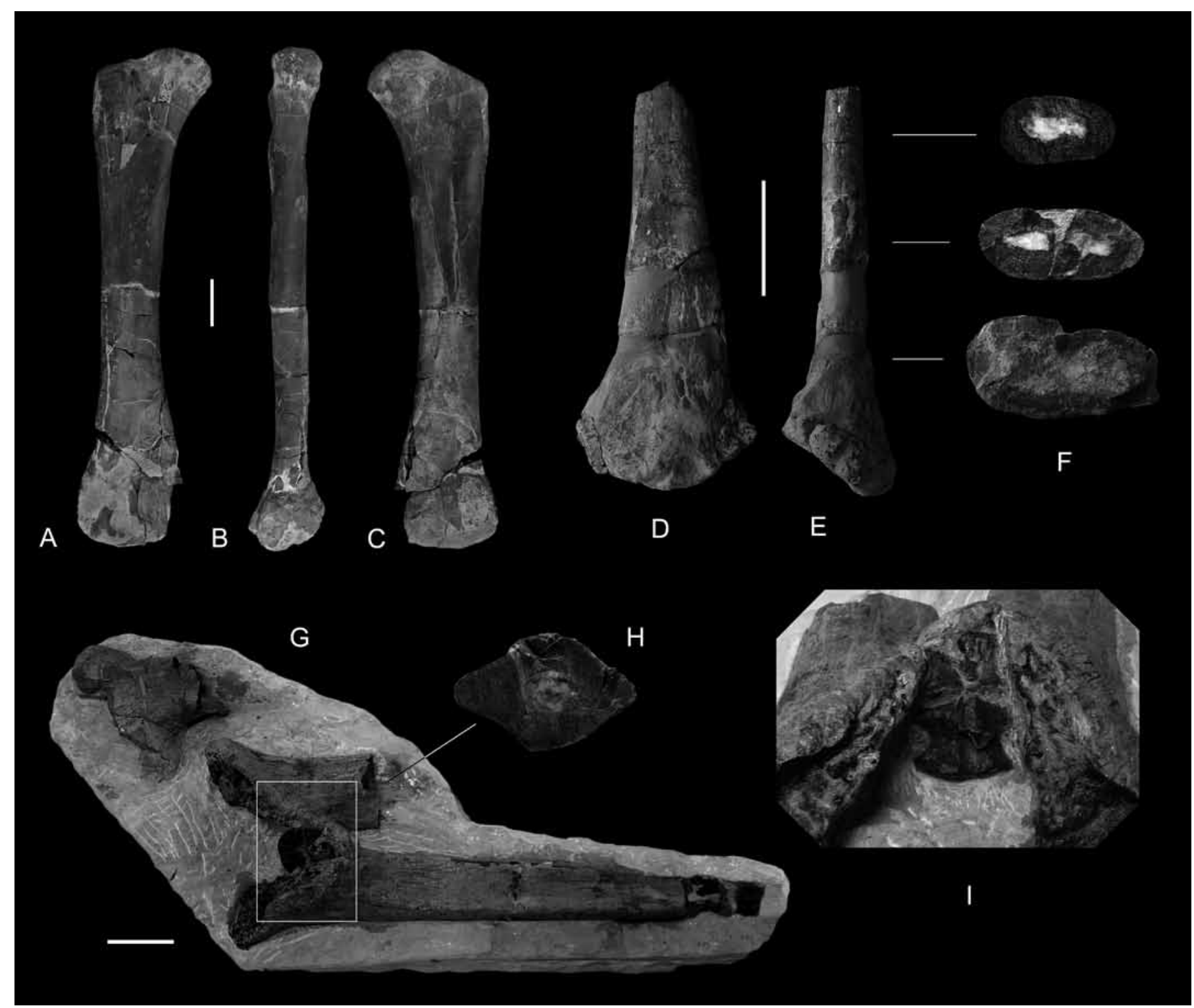

Fig. 4. H-M, Stegosaurian remains (Dacentrurinae indet.) from the Villar del Arzobispo Formation at Valencia province, Spain (Barranco del Curro site). A-C, left femur (MPA D-311) in anterior (A), medial (B) and posterior views (C). D-F, Left dermal tail spine (MPA D-316) in dorsal (D) and posterior (E) views, showing details of the cross sections of the spine (F). G-I, Distal tail spines and caudal vertebrae. G, sandstone slab with tail spines (MAP D-313/315) and associated caudal vertebrae (MAP D-327, 329). H, cross section of distal tail spine (MPA D-314). I, detail of caudal vertebrae co-ossified with the distal tail spines. Scale bar from A-E, G, I = $10 \mathrm{~cm}$. Figures F, H not to scale.

Fig. 4. H-M, Restos de dinosaurios estegosaurios (Dacentrurinae indet.) de la Formación Villar del Arzobispo (Barranco del Curro, provincia de Valencia, España). A-C, fémur izquierdo (MPA D-311) en vistas anterior (H), medial (I) y posterior (J). D-F, espina caudal izquierda (MPA D-316) en vistas dorsal (D) y posterior (E), mostrando secciones transversales de la espina (F). G-I, espinas distales y vértebras caudales. G, placa de arenisca con espinas caudales (MAP D-313/315) y vértebras caudales asociadas (MAP D-327, 329). H, sección transversal de una espina caudal distal (MPA D-314). I, detalle de las vértebras caudales coosificadas con las espinas caudales. Escala en A-E, G, I=10 cm. Las figuras F, H no están representadas a la misma escala.

(see Christiansen, 2007). Many thyreophorans have transverse processes that project dorsolaterally, rather than laterally. As noted by Maidment et al. (2008), the angle that the transverse processes make with the horizontal varies along the vertebral column, and is susceptible of deformation by taphonomical biases. Nevertheless, the low projection of the dorsal transverse processes relative to the horizontal distinguishes La Yesa taxon and Dacentrurus (Galton, 1985, 1991) from other stegosaurs. According to the features observed on its posterior dorsal vertebrae, and in absence of middle and posterior dorsal vertebrae in Miragaia, El Balsón stegosaur is provisionally referred to Dacentrurinae indet. 


\subsection{Barranco del Curro specimen}

Dacentrurinae indet.

(Figs. 2B, 4A-I)

Material: A partial skeleton composed of a complete femur (MPA D-311), a partial scapula (MPA D-312), four isolated dermal tail spines (MPA D-313/316), two of them articulated with two distal caudal centra (MPA D-327, 329).

Locality and horizon: Barranco del Curro site, placed in the vicinity of Baldovar village, Valencia province, Spain. Lower part of the Villar del Arzobispo Formation.

Age: Late Jurassic-Early Cretaceous transition (Tithonian-Berriasian).

\section{Description}

Caudal vertebrae.- Two distal caudal vertebrae coosified with the first pair of the terminal tail spines are partially exposed on the slab (Figs. 4G,I). The centra are short, platycoelous, narrow in their mid-section and expanded in the articular ends. The anterior end is slightly wider than the posterior end. The neural canal is broad but shallow, and the neural arch is placed posteriorly.

Scapula.- A fragmentary left scapula including most of the blade is preserved (Fig. 2B). The scapular blade is long, slenderly built, and parallel-sided. The dorsal margin is straight and the ventral margin gently curves at the contact with the proximal plate.

Femur.- A complete left femur $103 \mathrm{~cm}$ long is preserved (Figs. 4A-C). The femur is a straight bone, with a transversely wide columnar shaft, slightly compressed anteroposteriorly, showing at mid section a subrectangular shape. The head of the femur, not distinctly set off from the shaft, is markedly elevated above the greater trochanter, forming an angle of about of $110-115^{\circ}$ with the long axis of the shaft. The lesser trochanter is fused to the greater trochanter. The distal condyles, badly eroded, are separated by a wide intercondylar groove. The fourth trochanter is scarcely noticeable.

Dermal tail spines.- Four tail spines are preserved in the slab (Figs. 4D-I). One pair is fused to distal caudal centra (Fig. 4G-I). These spines are elongate (at least 63 $\mathrm{cm}$ long as preserved), exhibiting a moderately expanded base and well defined lateral and medial edges. The cross section is subrhomboidal in outline, and the broken basal section shows a thick cortex surrounding a central cavity (Fig. 4H). The specimens are quite similar to an isolated spine from the close locality Aras de los Olmos (MCNV Lo-1) referred to Dacentrurus by Casanovas et al. (1999). These long spines are regarded as the terminal pair of the dermal armour, and were probably posterolaterally projected well beyond the distal end of the vertebral column, as in Stegosaurus (Gilmore, 1914; Carpenter and Galton, 2001) and Kentrosaurus (Galton, 1982).

Two incomplete, isolated spines are also preserved in the slab. They probably correspond to the second pair of distal caudal spines (see Carpenter and Galton, 2001). These spines are noticeably expanded at the base, oval on cross-section (see figures 4D-F), and appear to be shorter than the terminal spines (about $35 \mathrm{~cm}$ long as preserved the most complete specimen; estimated length ca. 40 $\mathrm{cm})$. The external surface of all the spines is sculptured with vascular grooves. Transverse sections of the spine display a cortical region enclosing a large medullar cavity devoid of trabeculae (Fig. 4F).

\section{Discussion}

The material of Baldovar is referred to Stegosauria by the presence of a parallel-sided blade of the scapula, an indistinct fourth trochanter on the femur, and paired dermal spines on the tail (Galton and Upchurch, 2004; Maidment et al., 2008). The spines, provided of well defined lateral and medial edges, look like those of Dacentrurus (BMNH 46013; MCNV Lo-1) in that the transverse width is greater than the anteroposterior length (Galton, 1985; Galton and Upchurch, 2004; this character is not taken into account by Maidment et al. 2008). Pending complete preparation of the dermal elements, the Baldovar material is provisionally referred to Dacentrurinae indet.

\section{Conclusions}

Stegosaurian remains are relatively common in the Upper Jurassic and in Jurassic-Cretaceous transitional formations of the Iberian Peninsula. Most of the Iberian material, which comes from Portuguese localities, has been referred to Dacentrurus. Recent discoveries in the Late Jurassic of Portugal indicate the presence of different taxa, such as Stegosaurus and Miragaia. In Spain, only Dacentrurus is known in the fossil record (Valencia, Teruel and, with reservations, Burgos provinces). In this paper, new stegosaurian fossils from two new localities (La Yesa and Baldovar) of the Jurassic-Cretaceous transition of Valencia are reported. The new specimens consist of partial postcranial skeletons with closely or fully articulated bones, including a noticeable terminal pair of dermal spines associated to distal caudal vertebrae in the Baldovar specimen - the first one found in the Spanish record. La Yesa specimen exhibits a combination of features on the dorsal vertebrae that is only known in the genus Dacentrurus. All the material is preliminarily re- 
ferred to Dacentrurinae indet., as these features cannot be tested in Miragaia because the lack of homologous material in the Portuguese specimen.

\section{Note Added in Proof:}

Since this manuscript was submitted for publication, a new paper updating the stegosaur record of the Teruel province was published (Cobos et al., 2010). In this work, the postcranial remains from the "Barrihonda-El Humero", "El Romeral", "Prado de las Arenas" and "La Quineta 2" sites, in Riodeva (Table 1), are described and referred to aff. Dacentrurus sp. (Cobos, A., Royo-Torres, R., Luque, L., Alcalá, L., Mampel, L. (2010): An Iberian stegosaurs paradise: The Villar del Arzobispo Formation (Tithonian-Berriasian) in Teruel (Spain). Palaeogeography, Palaeoclimatology, Palaeoecology, 293: 223-236).

\section{Acknowledgements}

The authors are very grateful to Marçal Joanes-Roses and Gabriel Sanz who found the specimens. Field works were supported by Generalitat Valenciana and La Yesa City Council. This research was supported by the Ministerio de Ciencia e Innovación (MICINN, projects CGL2007-62469/BTE and CGL2007-64061/BTE; JIR-O and XPS), the Gobierno Vasco/EJ (GIC07/14-361; XPS) and the Principado de Asturias (Protocol CN-04-226; JIR-O). We acknowledge the valuable suggestions made by reviewers Peter Galton and David B. Weishampel.

\section{References}

Buffetaut, E., Morel, N. (2009): A stegosaur vertebra (Dinosauria: Ornithischia) from the Callovian (Middle Jurassic) of Sarthe, western France. Comptes Rendus Palevol, 8: 545-549. http:// dx.doi.org/10.1016/j.crpv.2009.05.001

Carpenter, K., Galton, P.M. (2001): Othniel Charles Marsh and the myth of the eight-spiked Stegosaurus. In: K. Carpenter (ed.), The armored dinosaurs. Indiana University Press, Bloomington and Indianopolis: 76-102.

Casanovas-Cladellas, M.L., Santafé-Llopis, J.V., Pereda-Suberbiola, J., Santisteban-Bové, C. (1995a): Presencia, por primera vez en España, de dinosaurios estegosaurios (Cretácico inferior de Aldea de Losilla, Valencia). Revista Española de Paleontología, 10: 83-89.

Casanovas-Cladellas, M.L., Santafé-Llopis, J.V., SantistebanBové, C. (1995b): Dacentrurus armatus (Stegosauria, Dinosauria) del Cretácico inferior de los Serranos (Valencia, España). Revista Española de Paleontología, 10: 273-283.

Casanovas-Cladellas, M.L., Santafé-Llopis, J.V., Pereda-Suberbiola, X. (1997): Nuevo material de estegosaurios en el Cretácico
Inferior de Valencia (Aras de Alpuente, localidad de Losilla I). Paleontologia i Evolució, 28-29: 269-274.

Casanovas-Cladellas, M.L., Santafé-Llopis, J.V., Santisteban Bové, C., Pereda Suberbiola, X. (1999): Estegosaurios (Dinosauria) del Jurásico superior-Cretácico inferior de la Comarca de los Serranos (Valencia, España). Revista Española de Paleontología, $\mathrm{n}^{\mathrm{o}}$ extraordinario: 57-63.

Christiansen, N. (2007): Analyse phylogénétique, évolution et paléobiologie des Stegosauria (Dinosauria: Thyreophora) et test de l'utilité des caractères morphométriques en cladistique. Master 2 dissertation, Université Pierre et Marie Curie and Muséum National d'Histoire Naturelle, Paris. 73 p. (unpublished).

Cobos, A. (2009): Stegosarian dinosaurs from the Villar del Arzobispo Formation of Teruel, Spain. Symposium on Stegosauria Switzerland. Abstracts of the Scientific Meeting at the Sauriermuseum Aathal: p. 2.

Cobos, A., Royo-Torres, R., Alcalá, L. (2008): Presencia del estegosaurio Dacentrurus en Riodeva (Teruel). Libro de resúmenes XXIV Jornadas de la Sociedad Española de Paleontología, Colunga: p. 89-90.

Cobos, A., Royo-Torres, R., Alcalá, L., Luque, L., Mampel, L. (2009): Stegosaurian dinosaurs from the Villar del Arzobispo Formation of Teruel (Spain). Tenth international Symposium on Mesozoic Terrestrial Ecosystems and Biota, Teruel: p. 135-136.

Escaso, F., Ortega, F., Dantas, P., Malafaia, E., Pimentel, N.L., Pereda-Suberbiola, X., Sanz, J.L., Kullberg, J.C., Kullberg, M.C., Barriga, F. (2007): New evidence of shared dinosaur across Upper Jurassic Proto-North Atlantic: Stegosaurus from Portugal. Naturwissenschaften, 94: 367-374. http://dx.doi.org/10.1007/s00114-006-0209-8

Escaso, F., Ortega, F., Dantas, P., Malafaia, E., Silva, B., Sanz, J.L. (2008): Estudio preliminar del material del estegosáurido de Vale Pombas (Portugal): nueva evidencia de Stegosaurus en el Jurásico Superior del suroeste europeo. Libro de resúmenes XXIV Jornadas de la Sociedad Española de Paleontología, Colunga: p. 107-108.

Galton, P.M. (1982): The postcranial anatomy of the stegosaurian dinosaur Kentrosaurus from the Upper Jurassic of Tanzania, East Africa. Geologica et Palaeontologica, 15: 139-160.

Galton, P.M.(1985): British plated dinosaurs (Ornithischia, Stegosauridae). Journal of Vertebrate Paleontology, 5:, 211-254. http://dx.doi.org/10.1080/02724634.1985.10011859

Galton, P.M. (1991):. Postcranial remains of stegosaurian dinosaur Dacentrurus from Upper Jurassic and Portugal. Geologica et Palaeontologica, 25: 299-327.

Galton, P.M., Upchurch, P. (2004): Stegosauria. In: D.B. Weishampel, P. Dodson, H. Osmólska (eds.), The Dinosauria, Second Edition. University of California Press, Berkeley, Los Angeles and London: 343-362.

Gilmore, C. W. (1914): Osteology of the armored Dinosauria in the United States National Museum, with special reference to the genus Stegosaurus. Bulletin of the United States National Museum, 89: 1-143.

Luque, L., Cobos, A. Royo-Torres, R., Espílez, E., Alcalá, L. (2005): Caracterización de los depósitos con dinosaurios de Riodeva (Teruel). Geogaceta, 38: 27-30. 
Maidment, S.C.R., Norman, D.B., Barrett, P.M., Upchurch, P. (2008): Systematics and phylogeny of Stegosauria (Dinosauria: Ornithischia). Journal of Systematic Palaeontology, 6: 367-407. http://dx.doi.org/10.1017/S1477201908002459

Marsh, O.C. (1877): New order of extinct Reptilia (Stegosauria) from the Jurassic of the Rocky Mountains. American Journal of Science (Series 3), 14: 513-514.

Mas, J.R., Alonso, A., Meléndez, N. (1984): La formación Villar del Arzobispo: un ejemplo de llanuras de marea siliciclásticas asociadas a plataformas carbonatadas. Jurásico terminal (NW de Valencia y E de Cuenca). Publicaciones de Geología, Universidad Autónoma de Barcelona, 20: 175-188.

Mateus, O., Maidment, S.C.R., Christiansen, N.A. (2009): A new long-necked "sauropod-mimic" stegosaur and the evolution of the plated dinosaurs. Proceedings of the Royal Society B: Biological Sciences, 276: 1815-1821. http://dx.doi.org/10.1098/rspb.2008.1909

Owen, R. (1842): Report on British fossil reptiles. Part II. Report of the Eleventh Meeting of the British Association of the Advancement of Science, 1841: 60-204.

Pereda Suberbiola, X., Galton, P.M., Torcida, F., Huerta, P., Izquierdo, L.A., Montero, D., Pérez, G., Urién, V. (2003): First stegosaurian dinosaur remains from the Early Cretaceous of Burgos (Spain), with a review of Cretaceous stegosaurs. Revista Española de Paleontología, 18: 143-150.

Pereda Suberbiola, X., Galton, P.M., Ruiz-Omeñaca J.I., Canudo, J.I. (2005): Dermal spines of stegosaurian dinosaurs from the Lower Cretaceous (Hauterivian-Barremian) of Galve (Teruel, Aragón, Spain). Geogaceta, 38: 35-38.

Royo-Torres, R., Cobos, A., Alcalá, L. (2006): A giant european dinosaur and a new sauropod clade. Science, 314: 1925-1927. http://dx.doi.org/10.1126/science.1132885
Royo-Torres, R., Cobos, A., Luque, L., Aberasturi, A., Espílez, E., Fierro, I., González, A., Mampel, L, Alcalá, L. (2009): High European sauropod dinosaur diversity during Jurassic-Cretaceous transition in Riodeva (Teruel, Spain). Palaeontology, 52: 10091027. http://dx.doi.org/10.1111/j.1475-4983.2009.00898.x

Ruiz-Omeñaca, J.I. (2000): Restos de dinosaurios (Saurischia, Ornithischia) del Barremiense superior (Cretácico inferior) de Castellote (Teruel) en el Muséum National d'Histoire Naturell de París. Mas de las Matas, 19: 39-119.

Ruiz-Omeñaca, J.I., Canudo, J.I. (2003): Dinosaurios (Saurischia, Ornithischia) en el Barremiense (Cretácico Inferior) de la Península Ibérica. In: F. Pérez-Lorente (Coord.), Dinosaurios y otros Reptiles Mesozoicos en España. Ciencias de la Tierra, 26, Instituto de Estudios Riojanos, Logroño: 269-312.

Ruiz-Omeñaca, J., Piñuela, L., Garcia-Ramos, J., Pereda-Suberbiola, X. (2009): A dacentrurine stegosaur from the Late Jurassic of Asturias (northern Spain). Journal of Vertebrate Paleontology, 29 (Supplement to Number 3): 174A.

Santafé Llopis, J.V. (1996): Los estegosaurios y su presencia en el Mesozoico de "Los Serranos" (Valencia). Zubia, 14: 105-111.

Seeley, H.G. (1887): On the classification of the fossil animals commonly called Dinosauria. Proceedings of the Royal Society, London, 43: 165-171.http://dx.doi.org/10.1098/rspl.1887.0117

Suñer, M., Martín, M. (2009): Un nuevo yacimiento del tránsito Jurásico-Cretácico de Alpuente (Los Serranos, Valencia, España): resultados preliminares. Paleolusitana, 1: 441-447.

Weishampel, D.B., Barrett, P.M., Coria, R., Le Loeuff, J., Xu X., Zhao X., Shani, A., Gomani, E.M.P., Noto, C.R. (2004): Dinosaur distribution. In: D.B. Weishampel, P. Dodson, H. Osmólska (eds.), The Dinosauria, Second Edition. University of California Press, Berkeley, Los Angeles and London: 517-606. 